\title{
Problems of marine mammal conservation in Southeast Asia
}

\author{
WILLIAM F. PERRIN \\ Southwest Fisheries Science Center, La Jolla, California 92038,U.S.A (william.perrin@noaa.gov)
}

SUMMARY: The marine mammal fauna of Southeast Asia consists of approximately 30 species, about $1 / 4$ of the world's species, and includes several endemic species or subspecies. Examples of problems of conservation include bycatch in a tuna driftnet fishery, inshore habitat degradation, and depletion of humpback whales in the Philippines; possible disappearance of dolphins and porpoises from the Mekong Delta in Vietnam; and depletion of riverine dolphins and large bycatch in a shark fishery in Indonesia. Major causative factors include over-fishing, human overpopulation, development, vulnerability of marine mammals, and evolution of bycatch into directed dolphin fisheries. Needs are for inventory (stock identification and abundance estimation), bycatch monitoring, reduction of takes to sustainable levels, and regional international cooperation.

\section{KEY WORDS: dolphin, whale, porpoise, bycatch, driftnet, CMS}

\section{INTRODUCTION}

Southeast Asia as defined for the purposes of this review includes northern Australia (Timor and Arafura sea coasts), Brunei, Cambodia, China (including the southern mainland, Hong Kong and Macao), East Timor, Indonesia, Laos, Malaysia, Philippines, Singapore, Taiwan, Thailand and Vietnam. Myanmar is not included because it relates more to the Indian Ocean than to waters to the east. The south coast of China and the northern coast of Australia are included because they share marine mammal populations intimately with the neighboring countries that are usually considered to make up Southeast Asia.

About 30 species of marine mammals occur in Southeast Asia (Table 1), including about 29 cetaceans (the taxonomy is still unsettled) and the dugong. There are no seals, except occasional stragglers from other regions to the north. ${ }^{1)}$ This is about $1 / 4$ of the world's species. ${ }^{2}$ It is not a very long list. However, there is more diversity in the marine mammal fauna than this simple list of species would indicate. For example, there are at least two forms of the spinner dolphin, Stenella longirostris, in the region: a large pelagic pantropical form and a small shallow-water subspecies that is endemic to inner Southeast Asia, the dwarf spinner dolphin $S$. $l$. roseiventris. ${ }^{3)}$ There are also two forms of the Bryde's whale, Balaenoptera edeni. The pygmy form is endemic to the region and may be a separate species. ${ }^{4)}$ There are at least two geographic forms of the Irrawaddy dolphin, Orcaella brevirostris. ${ }^{5)}$ And it can be expected that all or most of the species will have two or more (maybe several) semi-isolated populations or stocks that should be managed and conserved separately.

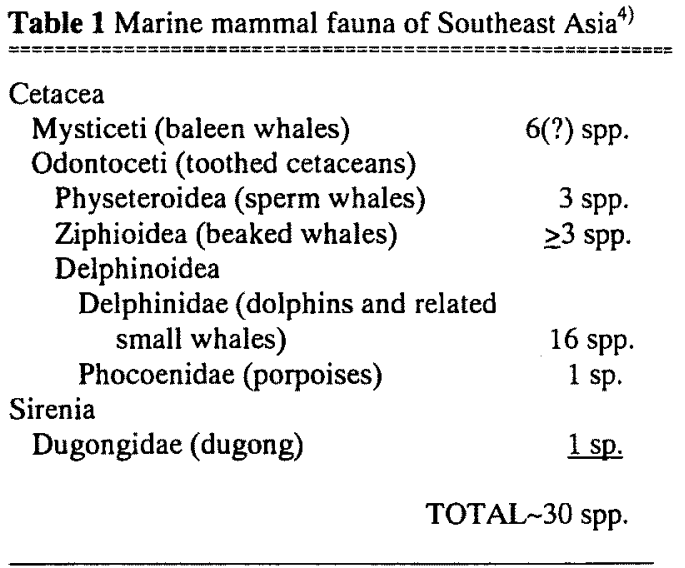

\section{CONSERVATION PROBLEMS}

There are urgent problems of conservation for a number of species and populations, in many parts of Southeast Asia. A limited number of examples in the Philippines, Vietnam, China and Indonesia are described briefly in this review.

\section{Philippines}

A driftnet fishery for tuna and other large pelagics in the eastern Sulu Sea takes cetaceans as bycatch. The driftnets are set in the waters of southern Negros and northern Mindanao by a fleet of about 50 small vessels. ${ }^{6)}$ The catch goes to fresh-fish markets. The cetacean bycatch includes mainly spinner dolphins, Stenella longirostris, and Fraser's dolphins, Lagenodelphis hosei. The nets also catch small 
whales, such as Cuvier's beaked whale, Ziphius cavirostris. A local market has developed from the by-caught dolphins and whales, so they are saved and sold. This is illegal, but the ban is very hard to enforce.

In 1994 and 1995, an international team carried out a survey of the eastern Sulu Sea to estimate the abundance of dolphins. ${ }^{7}$ The effort was sponsored by Silliman University in the Philippines, the Southwest Fisheries Center of the U.S. Marine Fisheries Service, the U.S. National Science Foundation and the International Foundation for Science. The survey track covered approximately 2,300 km. Estimated abundance for the spinner dolphin was approximately $30,000(95 \%$ CI 17,000 52,000 ) and for Fraser's dolphin about 11,000 (CI 6,000-21,000). A safe take from a dolphin population would be about $1-2 \%$ annually. ${ }^{8)}$ For these populations that would be about $300-600$ spinner dolphins and about 100-200 Fraser's dolphins, based on the central estimates of population size. If the confidence intervals are taken into account (as a precautionary measure), at the lower end that drops to about 200-300 spinner dolphins and 50-100 Fraser's dolphins. The few bycatch data we have for the driftnet fishery suggest that the kills are higher than this. ${ }^{7,9)}$ It is safe to say that these dolphin populations are probably declining. Until we get better data on the size and structure of the bycatch, we won't know how fast the decline is.

The next example is that of dolphins in Malampaya Sound on the east coast of Palawan Island, on the South China Sea. The only know remaining population of Irrawaddy dolphins, Orcaella brevirostris, in the Philippines occurs in the very shallow waters of Malampaya Sound. These same waters are very intensively fished with nets and traps and clogged with all kinds of structures. ${ }^{10)} \mathrm{A}$ recent survey resulted in an estimate of only about 50 dolphins remaining. ${ }^{11)}$ They are thought to have been more abundant before the fisheries expanded greatly during the last 20 years or so. The decline is due to incidental kill in fishing gear, over-fishing of the dolphins' food fish, habitat degradation caused by development and fishing activities, or some combination of all of these. A sustainable bycatch at present would be about one dolphin per year, and it is higher than that.

The last example for the Philippines is the precarious status of humpback whales, Megaptera novaeangliae, in the Babuyan Islands at the northern tip of the country. Humpback whales were once much more abundant in the North Pacific than they are at present. The stocks were greatly reduced by commercial whaling, which continued illegally on humpbacks by the Soviet Union into the 1970s. ${ }^{12)}$ Very recently, a small winter breeding population was discovered in the Babuyan Islands. ${ }^{13}$ ) This population was subject to Taiwanese whaling in relatively recent years and has become very smal! indeed (Yaptinchay AA, pers. comm., 1999). Humpback meat has appeared in DNA market surveys in Japan ${ }^{14)}$, and it is possible that it came from Philippine whales. Humpback whales can be individually identified from pigmentation patterns on their flukes. And of course they can be identified by their DNA sequences. Researchers in the Philippines are collecting fluke photographs and DNA samples from the humpback whales. They will try to estimate population size and, together with Japanese whale scientists, determine whether these whales are part of the same population that visits the Ogasawara Islands of Japan. Also, if one of the Philippine whales shows up in the meat markets of Japan or Korea, the DNA information will tell us where it came from.

\section{Vietnam}

Irrawaddy dolphins formerly occurred in the Mekong Delta in Vietnam, but surveys in 1995 and 1996 could find none. ${ }^{15)}$ The area was heavily covered with gillnets and fish traps, and this may account for the disappearance of the dolphins.

A driftnet fishery for large pelagics operates off the coast of northern Vietnam (Bui DC, pers. comm., 1998), as well as an extensive pair-trawl fishery. These types of fisheries are known to take cetaceans incidentally, but the bycatch has not been monitored or otherwise documented. The impact on cetacean populations is unknown.

\section{China}

Turning to China, Hong Kong is a bright spot for marine mammals in Southeast Asia. There is an ongoing program of marine mammal assessment and conservation there. ${ }^{16)}$ There are over 1000 humpback dolphins (Sousa chinensis, also called Chinese white dolphins) in Hong Kong waters and the Pearl River estuary. The population is being monitored and does not seem to be in immediate danger despite extensive habitat encroachment by new airport construction. The finless porpoise, Neophocaena phocaenoides, is also under study in Hong Kong; abundance is at least $220 .^{17)}$ 
The dugong, Dugong dugon, still occurs at Hainan Island and other parts of southern China but is severely endangered there. ${ }^{18)}$

\section{Indonesia}

Indonesia is a huge country. It dominates Southeast Asia in human population and in length of coastline. It also has many problems of marine mammal conservation.

In East Kalimantan on Bomeo, there is a small population of Irrawaddy dolphins in the Mahakam River system, which is separated from the ocean. Surveys of about $3,000 \mathrm{~km}$ of river in 1999-2000 yielded a preliminary population estimate of $33-50$ dolphins. ${ }^{11,19,20)}$ This population was recently listed by IUCN as Critically Endangered. The main cause of the decline appears to be bycatch in fisheries and live-capture for oceanaria. At least 30 dolphins have been removed from the river since 1974, for oceanaria in Jakarta and $\operatorname{Japan}^{20)}$ There are plans to remove more for a new oceanarium. This population appears headed for extinction urgent action is taken.

There is potentially a very large dolphin conservation problem in Indonesia in the Arafura and Timor Seas. From the mid-1970s to the early 1980s, Taiwan operated a large gillnet fishery for sharks in the EEZ of Australia. Australian observers on the boats collected bycatch data in the early $80 \mathrm{~s}$. The bycatch of dolphins over the period 1981-1985 was estimated at about $14,000{ }^{21)}$ About $2 / 3$ were Indopacific bottlenose dolphins, Tursiops aduncus, and about $1 / 3$ were dwarf spinner dolphins, Stenella longirostris roseiventris, a subspecies endemic to inner Southeast Asia. A few were of other species (Stenella attenuata, Sousa chinensis, Pseudorca crassidens). The shark catch ranged to about 30,000 metric tons during the period of the fishery in Australian waters. Because of the dolphin kill, the Taiwanese fishery in Australian waters was ended in 1986. However, the fishery then moved to Indonesian waters just to the north. ${ }^{22)}$ It presumably is affecting the same populations of dolphins (and sharks). At about the time that Taiwan was ejected from Australian waters because of the dolphin bycatch, the reported Taiwanese landings were about 35,000 metric tons (Figure 1). That almost doubled by 1990 but has declined since to about 15,000 tons. However, over the same period the reported landings of Indonesia have doubled to about 50,000 tons, so the total has remained roughly the same. We know that dolphin bycatch still occurs in these fisheries, and we suspect that the dolphin kills have been massive, but there are no data. And of course we have no idea of what the status of the dolphin populations might be.

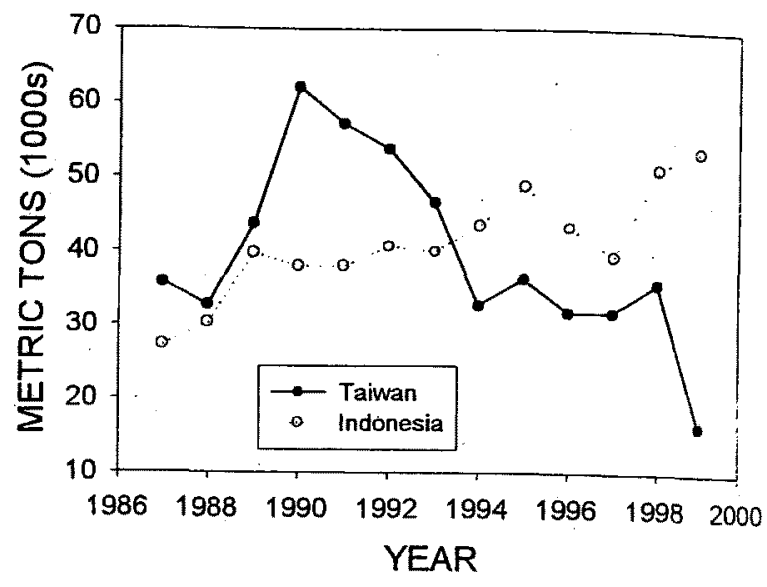

Fig. 1 Reported landings of sharks and other elasmobranchs by Taiwan and Indonesia in FAO Area 71, 1987-1999. ${ }^{28,29)}$

\section{CONCLUSIONS}

There are many other examples. Space does not permit describing them here. The species most affected are the humpback whale, three pelagic/coastal dolphins ( $S$. attenuata, S. longirostris, Lagenodelphis hosei), four inshore small cetaceans endemic to the IndoWest Pacific (Tursiops aduncus, Sousa chinensis, Orcaella brevirostris, Neophocaena phocaenoides) and the dugong. This is about $1 / 3$ of the marine mammal fauna of the region. There may be more that are seriously affected that we don't know about yet.

What are some of the factors that have led to the conservation problems of marine mammals? The effects of over-fishing are well known. It leads to probiems of resource depletion for all marine vertebrates. It is a very severe problem in Southeast Asia. The problems of human population growth and the environmental effects of development are also well known. Marine mammals are adversely affected by dams, effluents, pollutants and all the other agents of habitat destruction and degradation. Two other factors relate particularly to marine mammals (and marine turtles). The first is a special vulnerability to overexploitation; the second is a new phenomenon, the evolution of bycatches into dolphin fisheries. 
The main reason that marine mammals are so vulnerable to overexploitation is that they are $\mathrm{K}$ selected. Their intrinsic rates of increase are low, less than $10 \%$ and in some cases perhaps as low as 2$3 \%{ }^{8)}$ This is because they mature late, have a single offspring at intervals of up to 3 years, and have low natural mortality rates, some living as long as 100 years or more. So, in fishery terms, recruitment is tightly constrained within low bounds by stock size.

Another reason that marine mammals are so vulnerable is that they are easy to catch. ${ }^{23,24)}$ They get entangled in fishing nets and traps of all kinds and the small ones cannot break free. Because they must come to the surface to breathe, they are easy to find and easy to hunt. Some, like the dugong, have almost no chance to get away.

The other special problem of marine mammals is evolution of bycatch. Bycatch can lead to development of a directed fishery. In this evolution, first some fishermen retain and land the dolphins or porpoises caught incidentally in their nets. People buy the meat and decide they like it. It is usually cheaper than fish. So a demand develops. To satisfy the demand, the fishermen start to hunt the marine mammals. This has now happened in several parts of the world, including in Peru, Sri Lanka, West Africa and the Philippines. ${ }^{23,25)}$ Large unregulated dolphin fisheries have developed. These fisheries are exploiting unassessed populations, almost certainly at unsustainable levels. As human populations grow in Southeast Asia, and as overfishing depletes other sources of marine protein, we can expect this problem to increase and dolphin populations to further decline.

What must be done to save the marine mammals of Southeast Asia? A first important step is to inventory them. What are the stocks and how big are they? Most important is to estimate bycatch, by monitoring landings and sampling fisheries. Bycatches must be reduced to sustainable levels, through law enforcement, by establishing marine protected areas such as reserves and sanctuaries, by modifying fishing gear and methods, and by other means. Research toward these ends has begun in some Southeast Asian nations (Table 2), but in many cases it has barely started.

Regional cooperation is essential. Dolphins and whales are highly mobile, and all the nations in Southeast Asia share populations of them. Protection in one part of their range will not help much if they are being overexploited in another part of the range. This is exemplified by the failure of the Australian closure of the shark fishery in its waters to protect the dolphin populations there because they extend into Indonesian waters to the north. One vehicle for regional cooperation is the Convention on Migratory Species of Wild Animals, or CMS. The CMS has helped set up two regional agreements to conserve cetaceans: the Agreement on Small Cetaceans of the Baltic and North Seas (ASCOBANS) and the Agreement on Conservation of Cetaceans of the Black and Mediterranean Seas. CMS is currently working to develop similar agreements in southern South America and West Africa. One of the main tasks that ASCOBANS has set for itself in the North Atlantic and Baltic Sea is to assess the bycatch of harbor porpoises in fisheries. ${ }^{2())}$ This is because the harbor porpoise has all but disappeared in some areas and is declining in others. If there ever is a regional cooperative effort on marine mammals in Southeast Asia, under CMS or some other body such as ASEAN, in the future, this will also have to be its main and urgent task, to monitor and assess bycatch in fisheries in order to define the problems so that they can be addressed.

CMS is convening a second international

Table 2 Some centers of research on marine mammals of Southeast Asia

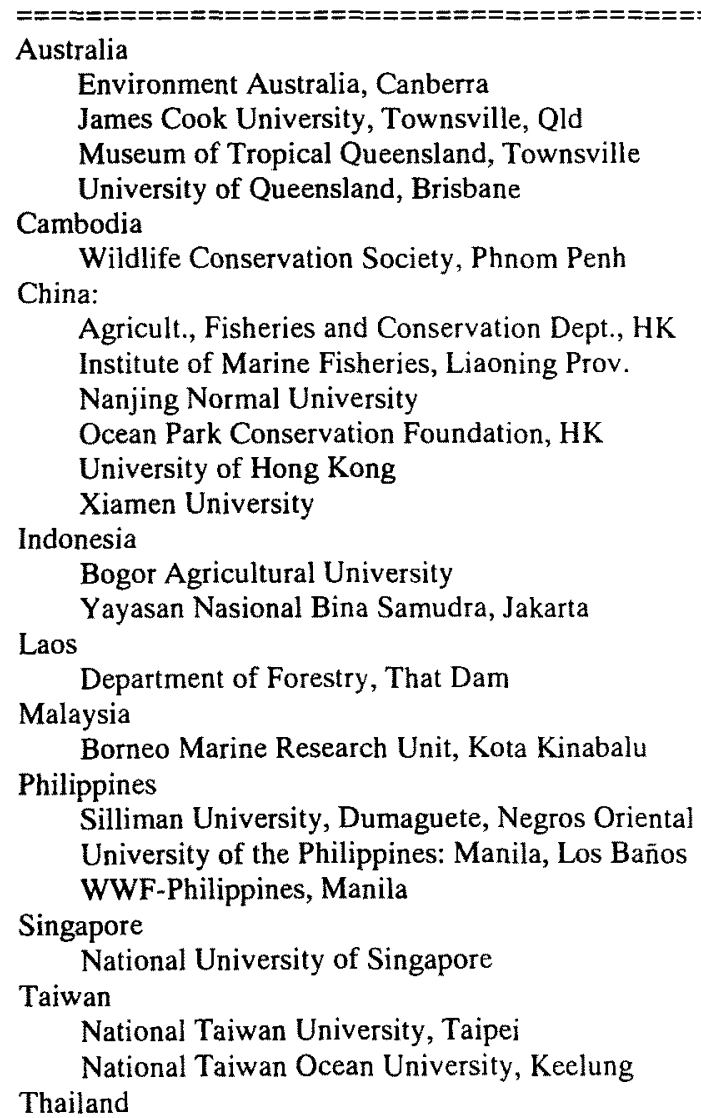


Phuket Marine Biological Center

Burapha University, Bangsaen

Katsetsart University

Vietnam

Institute of Oceanography, Nha Trang

Research Institute of Marine Products, Hanoi

Other

Southwest Fisheries Science Center, California

Zoological Museum, University of Copenhagen

conference on marine mammals of Southeast Asia in 2002 in the Philippines. The first conference was held in 1995. ${ }^{27)}$ The second conference will consist of a symposium and a workshop. The workshop will focus on bycatch. Further information is available from the author.

In summary, many marine mammal populations in Southeast Asia are in serious trouble. Some are close to extinction or extirpation. The major problem is bycatch in fisheries, although other problems include over-fishing, habitat destruction and live capture. Perhaps the greatest problem is that very little is known about fishery bycatch and status of habitat. The outlook is not very favorable, but it must be addressed, or many of the marine mammals of the region will disappear.

\section{REFERENCES}

1. Anderson, M, Kinze CC. Review and new records of the marine mammals and sea turtles of Indochinese waters. Nat. Hist. Bull. Siam. Soc. 2000;48:177-184.

2. Rice, DW. Marine mammals of the world. Soc. Mar. Mamm. Spec. Pub. 1998;4:1-231.

3. Perrin WF, Dolar MLL, Robineau D. Spinner dolphins (Stenella longirostris) of the western Pacific and Southeast Asia: pelagic and shallow-water forms. Mar. Mamm. Sci. 1999;15:1029-1053.

4. Perrin WF, Dolar MLL, Ortega E. Osteological comparison of Bryde's whales from the Philippines with specimens from other regions. Rep. Int. Whal. Commn. 1996;46:409-413.

5. Beasley I, Arnold P, Heinsohn G. Geographic variation in skull morphology of the Irrawaddy dolphin, Orcaella brevirostris (Owen in Gray, 1866). Raffles Bull. Zool. (Suppl.) In press.

6. Dolar MLL. Incidental takes of small cetaceans in fisheries in Palawan, Central Visayas and northern Mindanao in the Philippines. Rep. Int. Whal. Commn. Spec. Iss. 1994;15:355-363.

7. Dolar MLL. Abundance, distribution and feeding ecology of small cetaceans in the eastern Sulu Sea and Tañon Strait, Philippines. Ph.D. thesis, University of California, San Diego, 1999.

8. Wade PR, Angliss RP. Guidelines for assessing marine mammal stocks: report of the GAMMS workshop April 3-5, 1996, Seattle, Washington. NOAA Tech. Memo. NMFS 1997;NMFS-OPR-12:1-93.
9. Perrin WF, Dolar MLL. Preliminary results from spinner dolphins, Stenella longirostris, from the Philippines. IBI Rep. 1996;6:25-33.

10. Dolar MLL, Perrin WF, Gaudiano JP, Yaptinchay AASP, Tan JML. Preliminary report on a small estuarine population of Irrawaddy dolphins Orcaella brevirostris in the Philippines. Raffles Bull. Zool. (Suppl.) In press.

11. Smith BD, Jefferson TA. Status and conservation of facultative freshwater cetaceans in Asia. Raffles Bull. Zool. (Suppl.) In press.

12. Brownell RL Jr., Yablokov AV. Illegal and pirate whaling. In: Perrin WF, Würsig B, Thewissen H (eds). Encyclopedia of Marine Mammals. Academic Press, San Diego. 2001;608-611.

13. Yaptinchay AA. New humpback whale wintering ground in the Philippines. Abstracts $13^{\text {th }}$ Bienn. Conf. Biol. Mar. Mamm., Wailea, Maui, Hawaii, Nov. 28-Dec. 3, 1999:206.

14. Baker GS, Palumbi SR. Which whales are hunted? A molecular genetic approach to monitoring whaling. Science 1994;265:1538-1539.

15. Smith BD, Jefferson TA, Leatherwood S, Ho DT, Thuoc $\mathrm{CV}$, Quang LH. Investigations of marine mammals in Vietnam. Asian Mar. Biol. 1997;14:111-143.

16. Jefferson TA. Population biology of the Indo-Pacific hump-backed dolphin in Hong Kong waters. Wild!. Monogr. 2000;144:1-65.

17. Jefferson TA, Hung SK, Law L, Torey M, Treganza N. Distribution and abundance of finless porpoises in Hong Kong and adjacent waters of China. Raffles Bull. Zool. (Suppl.) In press.

18. Zhou K. Marine mammal research and conservation in China. Fish. Science (Suppl.); this issue.

19. Kreb D. Abundance and distribution of the pesut, Orcaella brevirostris in the Mahakam River, lakes and coast of East Kalimantan, Indonesia. Int. Whal. Commn. meeting document SC/52/SM32:1-21.

20. Kreb D. Density and abundance of the Irrawaddy dolphin, Orcaella brevirostris, in the Mahakam River of East Kalimantan, Indonesia: a comparison of techniques. Raffles Bull. Zool. (Suppl.); In press.

21. Harwood MB, Hembree D. Incidental catch of small cetaceans in the offshore gillnet fishery in northern Australia: 1981-1985. Rep. Int. Whal. Commn. 1987;37:363-367.

22. Liu HC. Geographic distribution of surface tuna resources in the Arafura and Timor Seas based on data collected from the Taiwanese fishing fleet. Presented at the Third Southeast Asian Tuna Conference, Bali, Indonesia, August 1989.

23. Perrin WF. Selected examples of small cetaceans at risk. In: Twiss JR Jr., Reeves RR, (eds). Conservation and management of marine mammals. Smithsonian Institution Press, Washington, D.C. 1999;296-310.

24. Perrin WF, Donovan GP, Barlow J (eds). Gillnets and cetaceans. Rep. Int. Whal. Commn. Spec. Iss. 15:1-629.

25. Van Waerebeek $K$, Ofori-Danson PK. A first checklist of cetaceans of Ghana, Gulf of Guinea, and a shorebased survey of interactions with coastal fisheries. Int. Whal. Commn. meeting document SC/51/SM35:1-9. 
26. Anon. Proceedings of the Third Meeting of Parties to ASCOBANS, Bristol, United Kingdom, 26-28 July 2000. ASCOBANS Secretariat, Bonn, Germany.

27. Perrin WF, Dolar MLL, Alava MNR. Report of the Workshop on the Biology and Conservation of Small Cetaceans and Dugongs of Southeast Asia. UNEP(W)/EAS WG 1996;1/2:1-101.

28. FAO. Table B-38. FAO Yearbook. Fishery Statisitics 1998;82/1.

29. FAO. Table B-38. FAO Yearbook. Fishery Statistics 2001;88/1. 